\title{
Effect of tillage as weed control method on maize (Zea mays L.) under Dongola area conditions- Northern State (Sudan)
} \author{
Asim Osman Elzubeir ${ }^{1}$ and Abdelmoniem Elamin Mohamed $^{2}$ \\ ${ }^{1}$ Faculty of Agricultural Science, University of Dongola, Dongola, Sudan. \\ Mobile: +249-123007626, E- mail: Asimosman11@hotmail.com \\ ${ }^{2}$ Faculty of Agriculture, University of Khartoum, Khartoum North, Sudan.
}

\begin{abstract}
A field experiment was conducted during two summer seasons; 2005/06 and 2006/07, at Dongola area- Northern State (Sudan). The objective was to investigate the effect of some tillage systems on weeds control on maize (Zea mays L.). The results indicate that tillage had no significant effect $(P \leq 0.05)$ on the number of broadleaf weeds and the total number of weeds, but they significantly affect $(P \leq 0.01)$ the number of grasses in both seasons. The tilled treatments reduced the total number of weeds in both seasons compared with no-tilled.
\end{abstract}

Keywords: Tillage, weed control, Maize (Zea mays L.), Dongola, Northern State- Sudan.

\section{INTRODUCTION}

Although many economic problems face maize producers, one of the major concerns is adequate control of weeds. Wilson and Foy (1990) reported that, many effective herbicides have been developed over the years, but still several weed species are not adequately controlled.

Zuofa and Tariah (1992) carried out a field experiment to investigate the effects of weed control methods on maize intercrop yields and net income of small-holder farmers in Nigeria, results indicated that yield reduction of up to $40 \%$ has been reported in maize crops grown without weed control.

Benson (1982) stated that, maize hand weeding trials indicated that the crop needs to be weeded two or more times during the early weeks but that once the crop is well established further weeding is often unnecessary.

FAO (1990) defined tillage as a set of operations performed on the soil to prepare a seedbed, control weeds and improve soil physical conditions for enhancing the establishment, growth and yield of crops, as well as conserving soil moisture.

Park and Eddowes (1975) reported that, an important aspect of tillage is to control weeds and so avoid serious competition during the seedling stage. This is done by ploughing which makes certain that the soil is properly inverted to control perennial weeds, and by destroying annual weeds that germinate before the crop is sown.

Munson (1976) stated that, weeds not only compete for water, nutrients, and light, but also slow down harvest speed and load combine screens. They make it much harder to get clean crop seed. So by loading the combine, some grain may be carried over and lost. Weed seeds often hold more moisture than crop seed or grain. Weeds cost producers in two wayswith their own seeds and with the higher moisture they put into the grain.

Tillage usually affects only one-tenth of the soil volume in which the root systems of most crops development (Arnon, 1972). About $75-80 \%$ of maize's root system concentrates in the $30-40 \mathrm{~cm}$ of the topsoil layer; therefore, tillage depth with 20-25 $\mathrm{cm}$ is necessary for the high-yield maize (NATESC, 2003).

Profitable production of maize requires that weed competition be minimized. Erbach and Lovely (1974) performed a study for weed control with conservation tillage production of corn and soybean, results indicated that conventional tillage (plough- discharrow) destroys weeds before planting and creates a soil condition favourable for control of 
Agric. Biol. J. N. Am., 2011, 2(3): 543-545

Table 1: The mean effect of tillage on weed types and population (plant $\mathrm{m}^{-2}$ ) at 20 days after planting for both seasons

\begin{tabular}{|c|c|c|c|c|c|c|}
\hline \multirow{3}{*}{ Tillage treatments } & \multicolumn{2}{|c|}{$\begin{array}{l}\text { Broadleaf weeds } \\
\text { (plant } \mathrm{m}^{-2} \text { ) }\end{array}$} & \multicolumn{2}{|c|}{$\begin{array}{c}\text { Grasses } \\
\text { (plant } \mathrm{m}^{-2} \text { ) }\end{array}$} & \multicolumn{2}{|c|}{$\begin{array}{c}\text { Total number of weeds } \\
\left(\text { plant } \mathrm{m}^{-2}\right)\end{array}$} \\
\hline & \multicolumn{2}{|c|}{ Seasons } & \multicolumn{2}{|c|}{ Seasons } & \multicolumn{2}{|c|}{ Seasons } \\
\hline & $2005 / 06$ & $2006 / 07$ & $2005 / 06$ & $2006 / 07$ & $2005 / 06$ & $2006 / 07$ \\
\hline$T_{1}$ & $74^{\mathrm{a}}$ & $76^{\mathrm{a}}$ & $66^{\mathrm{b}}$ & $67^{b}$ & $140^{\mathrm{a}}$ & $143^{\mathrm{a}}$ \\
\hline$T_{2}$ & $57^{a}$ & $58^{a}$ & $111^{\mathrm{a}}$ & $113^{\mathrm{a}}$ & $168^{\mathrm{a}}$ & $171^{\mathrm{a}}$ \\
\hline $\mathrm{T}_{3}$ & $29^{a}$ & $30^{a}$ & $144^{\mathrm{a}}$ & $147^{a}$ & $173^{\mathrm{a}}$ & $177^{a}$ \\
\hline Significance level & * & * & ** & ** & * & * \\
\hline
\end{tabular}

${ }^{*},{ }^{* *}$ Indicated significance at $\mathrm{P} \leq 0.05$ and $\mathrm{P} \leq 0.01$, respectively.

Means followed by the same letter(s) in a column are not significantly different according to Duncan's Multiple Range Test.

$\mathrm{T}_{1}=$ disc ploughing $(20 \mathrm{~cm}$ depth) followed by disc harrowing and levelling.

$\mathrm{T}_{2}=$ chisel ploughing ( $30 \mathrm{~cm}$ depth) followed by disc harrowing and levelling.

$\mathrm{T}_{3}=$ no tillage.

subsequent weed growth. Conservation tillage systems leave crop residue on the soil surface, leaves the soil surface rough, and do not always destroy all pre-planting weed growth.

Dowelbeit and Salih (1994) conducted a field experiment to study the effects of different tillage systems which included minimum tillage, disc harrow, heavy disc harrow, chisel plough, and disc plough plus disc harrow plus levelling on weed control. Results showed that there were no significant differences between treatments. However, it was noticed that the highest number of weed $/ \mathrm{m}^{2}$ in maize was at the minimum tillage this was followed by chisel ploughing.

Mohammed (2006) conducted a research work to examine importance and control of weeds in maize with special reference to the Northern State of Sudan, results obtained indicated that maize is relatively more tolerant to weeds in the winter season than in the summer season.

Field experiments were conducted for two consecutive summer seasons; 2005/06 and 2006/07, at Dongola area- Northern State; latitude $19^{\circ} 10^{\prime} \mathrm{N}$, longitude $30^{\circ} 29^{\prime} \mathrm{E}$, and altitude $228 \mathrm{~m}$. One of the objectives was to investigate the effect of tillage practices on weed control of maize (Zea mays L.). Weed types and population were identified at 20 days after planting, one day before the first weeding, in both seasons.

Table 1 summarizes the mean values (plant $\mathrm{m}^{-2}$ ) of the number of broadleaf weeds, number of grasses, and total number of weeds. The results observed that weed flora was the same in both seasons. Analyses of variance show that there were no significant differences $(P \leq 0.05)$ due to tillage on the number of broadleaf weeds and the total number of weeds in both seasons. Similar observations had been reported by Dowellbeit and Salih (1994) and Ahmed (2000). On the other hand, the number of grasses was highly significant $(P \leq 0.01)$ as affected by tillage practices in both seasons.

However, the tilled treatments gave the lowest number of grasses than no tillage treatment. Conversely the tilled treatments gave the highest number of broadleaf weeds than no tillage treatment. While the tilled treatments gave the lowest total number of weeds in both seasons, especially for disc ploughing treatment. This could be attributed to the fact that disc ploughing which makes certain that the soil is properly inverted to control perennial weeds, and by destroying annual weeds that germinate before the crop was sown, this in the same line with the findings of Park and Eddowes (1975).

On the basis of the results of this study the following conclusions can be drawn:

1. Disc ploughing treatment was found to be more effective in weeds control than chisel ploughing and no tillage treatments.

2. Weeds are the major inherent problem of notillage.

\section{REFERENCES}

Ahmed, B.M. (2000). Performance of Chisel and Disc Implements and their Effects on Sorghum and Maize in Gezira Vertisols. M.Sc. (Agric.) thesis. University of Khartoum, Khartoum, Sudan.

Arnon, I. (1972). Crop Production in Dry Regions. Leonard Hill Books, London. 
Agric. Biol. J. N. Am., 2011, 2(3): 543-545

Benson, J.M. (1982). Weeds in Tropical Crops: Review of Abstracts. Food and Agriculture Organization, United Nations, Rome, Italy.

Dawelbeit, M.I. and Salih, A.A. (1994). Evaluation of Minimum Tillage on Sorghum and Maize in Irrigated Vertisols of Sudan. International Soil Tillage Research Organization, Proceedings of the $13^{\text {th }}$ International Conference, pp. 783-788, Aalborg, Denmark.

Erbach, D.C. and Lovely, W.G. (1974). Weed Control with Conservation Tillage Production of Corn and Soybeans. Journal of Soil and Water Conservation 29(1), 44-45.

FAO (1990). Agricultural Engineering in Development: Tillage for Crop Production in Area of Low Rainfall. Food and Agriculture Organization, United Nations, Rome, Italy.

Mohammed, M.A. (2006). Weeds in Maize (Zea mays L.) (Importance and Control) with Special Reference to the Northern State of Sudan. Ph.D. (Agric.) thesis. Sudan
University of Science and Technology, Khartoum, Sudan.

Munson, R.D. (1976). Managing for Minimum Harvest Stress. Better Crops with Plant Food, Potash Institute, Atlanta, LX 1/76, 22-26.

NATESC (2003). Corn Cultivation Technology Training Course. National Agro-Technical Extension Service Centre, China.

Park, R.D. and Eddowes, M. (1975). Crop Husbandry. $2^{\text {nd }}$ edition. Oxford University Press.

Wilson, J.S. and Foy, C.L. (1990). Weed Control in NoTillage and Conventional Corn (Zea mays L.) with IC3A-051 and SC-0774. Weed Technology, a Journal of the Weed Science Society of America 4(4), 731-738.

Zuofa, K. and Tariah, N.M. (1992). Effects of Weed Control Methods on Maize and Intercrop Yields and Net Income of Small-holder Farmers, Nigeria. Journal of Tropical Agriculture 68(2). 